\title{
The Physico-chemistry and Distribution of Water Hyacinth (Eichhornia cressipes) on the river Nun in the Niger Nelta
}

\author{
*11NYANANYO, BL; ${ }^{2}$ GIJO AH; ${ }^{2}$ OGAMBA, EN; \\ ${ }^{* 1}$ Department of Plant Science and Biotechnology, University of Port Harcourt, P.M.B. 5323, Port Harcourt, Rivers State, Nigeria. \\ ${ }^{2}$ Department of Biological Sciences, Niger Delta University, Wilberforce Island \\ P.M.B 071, Yenagoa Bayelsa State,Nigeria.
}

\begin{abstract}
The physicochemical studies and phytochemical investigations of River Nun and the water hyacinth (Eichhornia crassipes) were carried out in relation to the distribution of Eichhornia crassipes (Mart) Solms, Family Pontederiaceae in the River Nun.. The physicochemical studies of the water showed that dissolved oxygen (DO), biochemical oxygen demand $(\mathrm{BOD})$, nitrate $\left(\mathrm{NO}_{3}\right)$, salinity and alkalinity $(\mathrm{pH})$ had mean $+\mathrm{SD}$ values of $6.94+0.22,5.86+0.42 \mathrm{mg} / \mathrm{L}, 13.76+5.76 \mathrm{mg} / \mathrm{L}, 0.237+0.082 \mathrm{mg} / \mathrm{L}, 7.25+0.37 \mathrm{mg} / \mathrm{L}$ and $5.92+0.32$ $\mathrm{mg} / \mathrm{L}$ respectively. Phosphate $\left(\mathrm{PO}_{4}\right)$ and sulphite $\left(\mathrm{SO}_{3}\right)$ were not detected. The $\mathrm{pH}$ and DO levels appeared to favour the growth of E. crassipes.The BOD values were relatively higher than those of the control. The phytochemical studies showed that E. crassipes contains flavonoids (luteolin, apigenin, tricin, chrysoeriol, kaempferol, azaeleatin, gossypetin and orientin), amino acids (methionine, valine, glutamic acid theonine, tryptophan, tyrosine, leucine and lysine), phosphorous, protein, organic matter and cyanide. Some of these phenolic compounds and cyanide contribute to the negative impact associated with the proliferation of $E$. crassipes, in aquatic systems in addition to blocking water ways. The high protein and total organic matter content of Eichhornia crassipes, however, make E. crassipes a potential raw material for the production of animal feed and organic fertilizers. The study also shows that this plant prefers an almost neutral $\mathrm{pH}$ aquatic environment with a substantial concentration of dissolved oxygen, an increased rate of biochemical oxygen demand with a substantial concentration of nitrates. These conditions explain why this plant thrives in freshwater habitats such as the River Nun.@JASEM
\end{abstract}

Eichhornia crassipes is an erect free-floating and stoloniferous perennial herb, which belongs to the Family Pontederiaceae. It was first reported in Africa, in the Nile River in 1956 and has spread by 1966 to the Jebel Aulia Dam near Kherfoun (Cook, 1976). Consequently, this invasive plant was reported in Lagos, Nigeria in 1984, nearly one hundred years after it was introduced into the United States from South America at the world's Industrial and Cotton Continental Exposition of 1884-1885 in New Orleans, Louisiana, by a Florida visitor to the exposition in 1884 (Tabita and Woods, 1962). Since then, the plant has spread to other parts of Nigeria like confluence of rivers in Lokoja, and rivers and river systems in the Niger Delta such as New Calabar river in Choba, Ase river in Aghalokpe, Sombreiro river in Ahoada, Ekole creek in Yenagoa, Nun river in Amassoma, etc. (Nyananyo, et al., 2005)

All species of Eichhornia, except the African species, E. natans occur naturally in tropical South America where they are believed to have originated, and form conspicuous component of aquatic vegetation of shallow pools, lakes, ponds and rivers. Eichhornia sp. is probably the most invasive and prolific plant species in the world's rivers and canals. The plant has a doubling time of 6-18 days and a leaf turn-over rate of $60-70 \%$ per month (Mitchell, 1974; Center and Spencer, 1981; Schmite, et al., 1993). The environmental hazards associated with large $E$. crassipes populations is degraded water quality and drastic changes in the plant and animal community, light and oxygen diffusion are severely curtailed by this floating plant, reduction in water movement and the decomposition of the plants, if large biomass of the plants are killed at once, can use up all the oxygen in the water (Gopal,1987). Other environmental hazards associated with this plant which can live and reproduce floating freely on the surface of fresh water or anchored in mud include clogging of irrigation, hydropower and water supply ways. Hindrance of water transport, blockage of canals and rivers causing flooding (Bos, 1996). Healthwise, the fibrous root system of E. crassipes provide nesting habitat for a variety of disease vectors (Lymphatic filariasis, Malaria and Schistosomiasis).

Despite all the problems created by E. crassipes, some positive reports have been recorded. Gopal (1987) reported that E. crassipes contains $64 \%$ methane and can be used for biogas generation and for water purification. It is also valuable in traditional medicine, making of ropes, production of fibre boards, as animal fodders and fish feed, green manure, compost, and as an ornamental plant. The crushed roots can be used for making briquettes for fueling of stoves and for paper production (Isichei, et al., 2003). However, there has been no information on the phytochemical status of this plant. Therefore, 
the aim of this project was to investigate the phytochemical staus of E. crassipes and determine some physiochemicalparameters that may enhance its growth in the Nun River that may be responsible for the distribution, growth, and proliferation of this plant in situ.

\section{MATERIALS AND METHODS}

The study area is the River Nun in Amassoma and environs in the Southern Ijaw Local Government Area of Bayelsa State. The town is situated about $40 \mathrm{~km}$ west of Yenagoa, located approximately between latitudes $4^{\circ} 15^{\prime}$ ' to $4^{\circ} 50^{\prime \prime} \mathrm{N}$ and $6^{\circ} 50^{\prime}$ ' to $7^{\circ} 50^{\prime}$ 'E within the Niger Delta. The River Nun is one of the major river systems of the Niger Delta. The others are the Forcados and Orashi river systems. There are riverine communities/settlements along the river with several pier toilets. The major means of transportation is by water with engine boats and local canoes. Fishing activities go on regularly in the river with several adjoining fish ponds. Nun river is a freshwater ecosystem. The climate is typically tropical with average all year temperature in the range of $25^{\circ} \mathrm{C}-30^{\circ} \mathrm{C}$ (Egborge and Sagay, 1979; Tetsola, 1988; Onwudinjo, 1990). A total of 6 stations located at approximately $1 \mathrm{~km}$ intervals were sampled. Station 6 is the control sited in a section of the river without any trace of Eichhornia sp. The samples were collected during the early rainy season, in the month of June, 2005.

\section{Sample Collection and Analysis: Eichhornia crassipes: The plants of Eichhonia crassipes were collected from the sample stations along the shoreline of River Nun in Amassoma. The five stations were located along the stretch of the river covered by mats of water hyacinth. After collection, the plant materials were oven dried in the laboratory, ground with an electronic blender and stored in plastic containers at room temperature for a week before they were analyzed.}

Phytochemical analysis carried out on the plant materials were based on the paper chromatographic method (Harborne, 1973). The chromatograms prepared from the plant materials were viewed under UV light for the identification of spots based on their RF values. The identification of the flavonoids were based on RF values, colour in UV plus Ammonia while that of amino acids were based on standard amino acid markers (APHA, 1976).
$R F=\frac{D M_{\text {sample }}}{D M_{\text {solvent }}}$

where $\mathrm{DM}_{\text {sample }}$ and DMsolvent are Distance moved by sample $(\mathrm{cm})$ and distance moved by eluting solvent $(\mathrm{cm})$ respectively.

The percentage crude protein, percentage cyanide, and Total organic matter contents of E. crassipes were determined using the ammonium distillate(boric acid solution) titration method, alkaline titration method, and combustion methods respectively, while the phosphate content was determined by sodium carbonate fusion method (Stewart et al., 1984 and APHA, 1976).

Water Quality: Samples for water quality studies were collected from the five stations where E. crassipes were collected using plastic containers. One other sample was collected from a section of the river not infested with water hyacinth as the control. Surface water samples were collected and analyzed at the University of Port Harcourt, Department of Plant Science and Biotechnology Anatomy and Physiology Laboratory. The concentrations of phosphate $\left(\mathrm{PO}_{3}\right)$, sulfate $\left(\mathrm{SO}_{4}\right)$ and nitrate $\left(\mathrm{NO}_{3}\right)$ were determined using spectrophotometric method (spectronic instrument model 21D) in conformity with the standard procedures as described in APHA, 1976. The $\mathrm{pH}$, was determined using a Cole Parmer Digisense meter (Cole Parmer, USA). Conductivity was measured with a Lovibond instrument model type (CM-21). Dissolved Oxygen (DO) was measured with a yellow springs DO meter and probe while the Biochemical Oxygen Demand (BOD) was determined following the Winkler's method as described in APHA, 1976.

\section{RESULTS AND DISCUSSION}

The results of the phytochemical investigations of $E$. crassipes and the phytochemical characteristic studies of the water in River Nun are presented in Tables $1-4$. Flavonoids and amino acids were detected in the samples of E. crassipes studied (Tables 1 and 2). Amino acids detected include glutamic acid, leucine, lysine, methionine, threonine, tryptophan and valine (Table 2). 
Table 1: Flavonoid Constituent of E. crassipes using various solvents.

\begin{tabular}{|c|c|c|c|c|}
\hline Flavonoid (Flavones) & BAW & $\begin{array}{l}\mathrm{RF}(\mathrm{x} 100) \text { in } \\
\text { forestall }\end{array}$ & $\begin{array}{l}50 \% \\
\text { Acetic } \\
\text { acid }\end{array}$ & $\begin{array}{l}\text { Colour in UV } \\
\& \text { UV plus } \\
\text { Ammonia }\end{array}$ \\
\hline Luteolin & 79.3 & 66.3 & 66.6 & Dull ochre \\
\hline Apigenin & 87.9 & 83.0 & - & Dull ochre \\
\hline Tricin & 73.4 & 72.84 & - & Yellow \\
\hline $\begin{array}{l}\text { Chrysoeiol } \\
\text { (Flavonols) }\end{array}$ & 81.8 & 77.0 & - & Yellow \\
\hline Kaempferol & 83.4 & 55.2 & 56.0 & Yellow \\
\hline Azaeleatin & - & - & 48.7 & Yellow \\
\hline $\begin{array}{l}\text { Gossypetin } \\
\text { (Glylsy flavone) }\end{array}$ & 31.2 & - & - & Dull black \\
\hline Orientin & 31.3 & - & - & Yellow \\
\hline
\end{tabular}

Note: BAW (Butanol : Acetic acid : Water =4:1:5\}; Forestall (Conc. HCl : Acetic acid : Water = 3: 30: 10\}; 50\% Acetic acid (Acetic acid : Water $=1: 1\}$

The high percentage total organic matter, crude protein and amino acids have all composition helped to explain why the plant is used as a valuable source of animal feed. Studies have shown that these nutrients in E. crassipes are a vital source of food for both ruminants and non ruminants. In South-East Asia, and Malaysia, some non ruminant animals are fed rations containing $E$. crassipes with vegetable wastes, rice, bran, copra cake and salt to make a suitable feed (Isichei, et. al. 2003). Eichhornia. crassipes is ideal for composting and can also be used as green manure. As a green manure it can either be ploughed into the ground or used as mulch. However, the decomposition of E. crassipes can have adverse effects on the aquatic environment, as it increases the biological oxygen demand (BOD) in the water (Table 4) due to its high organic matter content. The phytochemical analysis also revealed that the percentage Cyanide ( $\% \mathrm{CN}$ ) in $E$ crassipes is about $0.0216 \mathrm{mg} / 100 \mathrm{~g}$. (Table 3). Cyanide is a toxic substance that adversely affects living organisms. The presence of cyanide in E. crassipes further explains the reason why most aquatic organisms (both plants and animals) are displaced or inhibited from areas that are infested by the plant. Indeed, it is the ability of cyanide ions to bond with iron ions that is partly responsible for their action as poisons. Cyanide interferes with the Cytochrome oxidize peroxidase and thus disrupts respiration with often fatal effects. The complexes of cyanide with zinc and cadmium are the most fatal. Concentrations of cyanide below $0.1 \mathrm{ppm}$ are rapidly fatal to fish. The cyanide on $E$. crassipes can be released into the water through decomposition.

The $\mathrm{pH}$ of the waters of River Nun $(6.94 \pm 0.22)$ (Table 4) favours the growth requirements of $E$. crassipes and other aquatic organisms.
Table 2: Amino Acid Constituent of E. crassipes using BAW

\begin{tabular}{lll}
\hline $\begin{array}{l}\text { Solvent } \\
\text { used }\end{array}$ & $\begin{array}{l}\text { Amino acid } \\
\text { identified }\end{array}$ & $\begin{array}{l}\text { Colour with 1\% } \\
\text { minhydrin tuv. }\end{array}$ \\
\hline BAW & Methionine & Violet \\
& Valine & Violet \\
& Glutamic Acid & Violet \\
& Threonine & Violet \\
& Tryptophan & Grey \\
& Tyrosine & Grey \\
& Leucine & Violet \\
\hline
\end{tabular}

Solvent key $: B A W=n$ Butanol - Acetic Acid-water $=4: 1: 5$

Table 3: Result of Analysis for various parameters in E. crassipes $(\mathrm{mg} / 100 \mathrm{~g})$.

\begin{tabular}{lllll}
\hline $\begin{array}{l}\% \\
\text { TOC }\end{array}$ & $\% \mathrm{CN}$ & $\% \mathrm{TOM}$ & $\begin{array}{l}\text { \% Crude } \\
\text { Protein }\end{array}$ & $\% \mathrm{PO}_{4}$ \\
\hline 1.26 & 0.0216 & 90.8 & 10.93 & 0.304 \\
\hline
\end{tabular}

It was also observed that there was just a little difference between the $\mathrm{pH}$ of the water that is underneath the mats of E. crassipes and that of the water that is free from E. crassipes mats. The concentration of the dissolved oxygen (DO) in the water is above the minimum limit of $5.0 \mathrm{mg} / \mathrm{l}$ in fresh water that is necessary for the survival of aquatic fauna (William, 1999). The values of BOD, however, showed great variation among the stations (Table 4) Whereas station 3 had the highest BOD concentrations of $12.8 \mathrm{mg} / \mathrm{l}$, station 2 had the lowest 
of and $8.0 \mathrm{mg} / \mathrm{l}$. This may be as a result of the fact that many of the plants were dead underneath the densely populated E. crassipes mats; since the percentage total organic matter $(\% \mathrm{TOM})$ in the plants are high (about $90.8 \mathrm{mg} / 100 \mathrm{~g}$ ) and thus, requires higher amounts of dissolved oxygen to decompose. Station 4 also has a relatively high amount of BOD. This is because it shares similar environmental factors with station 3 . The BOD in stations 2 and 5 were however the lowest $(8.0 \mathrm{mg} / \mathrm{l}$ and $9.6 \mathrm{mg} / \mathrm{l}$ respectively). This may be due to the high flow rate lesser dead plants in the stations. When the BOD in all the sample stations were correlated with that of the control, it was observed that the BOD in most of the sample stations were relatively higher than that of the control (Table 4).

of Benin City. Nigeria.

\begin{tabular}{|c|c|c|c|c|c|c|c|c|c|c|}
\hline water & $\begin{array}{l}\text { Sample } \\
\text { stations }\end{array}$ & $\mathrm{pH}$ & $\overline{\mathrm{DO}}$ & BOD & Conductivity & $\mathrm{PO}_{4}$ & $\mathrm{NO}_{3}$ & $\mathrm{SO}_{3}$ & Salinity & Alkalinity \\
\hline $\begin{array}{l}\text { these } \\
\text { station }\end{array}$ & Station 1 & 7.16 & 5.76 & 12.8 & 0.29 & NIL & 0.252 & NIL & 7.25 & 6.0 \\
\hline $\mathrm{s}$ and & Station 2 & 6.97 & 6.56 & 8.0 & 0.33 & NIL & 0.218 & NIL & 6.88 & 6.0 \\
\hline & Station 3 & 6.87 & 5.92 & 22.4 & 0.28 & NIL & 0.185 & NIL & 7.25 & 5.8 \\
\hline Table & Station 4 & 6.90 & 5.60 & 16 & 0.31 & NIL & 0.319 & NIL & 7.25 & 5.6 \\
\hline & Station 5 & 6.78 & 5.44 & 9.6 & 0.29 & NIL & 0.210 & NIL & 7.61 & 6.2 \\
\hline & $\operatorname{Mean}(\mathrm{X})$ & 6.94 & 5.86 & 13.76 & 0.30 & NIL & 0.237 & NIL & 7.25 & 6.92 \\
\hline & Confidence & $6.94 \pm$ & $5.86 \pm$ & $13.76 \pm$ & $0.30 \pm$ & NIL & $0.237 \pm$ & NIL & $7.25 \pm$ & $5.92 \pm$ \\
\hline & Limit & 0.22 & 0.42 & 5.76 & 0.02 & NIL & 0.082 & NIL & 0.37 & 0.32 \\
\hline & \multicolumn{10}{|c|}{ Control } \\
\hline & & $\mathrm{pH}$ & DO & $\mathrm{BOD}_{5}$ & Conductivity & $\mathrm{PO}_{4}$ & $\mathrm{NO}_{3}$ & $\mathrm{SO}_{3}$ & Salinity & Alkalinity \\
\hline & & 7.62 & 5.92 & 9.6 & 0.24 & NIL & 0.344 & NIL & 6.88 & 5.2 \\
\hline
\end{tabular}


The high concentration of dissolved oxygen and the absence of sulphates and phosphates may be attributed to the assertion that the water in the River Nun has a high rate of self-purification. Furthermore, it can be said that the high densities of E. crassipes in this river may be responsible for the depletion of these plants nutrients (phosphates, nitrate and sulphates) from the water. The plant is however, sustained by the presence of nitrates in the water, which are essential plant macronutrients.

The salinity of water $7.25 \mathrm{mg} / \mathrm{l}$ was low enough to favour the proliferation of $E$. crassipes. The salinity as well as the alkalinity showed very minimal variation among the stations (Table 4).

Conclusion: Eichhornia crassipes was found to be rich in flavonoids, amino acids, crude protein, cyanide, phosphate, organic matter and organic carbon. It grows in an almost neutral $\mathrm{pH}$, substantial concentration of dissolved oxygen, an increased rate of biochemical oxygen demand, a substantial concentration of nitrates, and very low salinity and alkalinity. The results of this study are in conformity with the phytochemical analytical results of this plant by Nyananyo et al., 2005. This shows that the plant is likely to be found in freshwater environments. However, the absence of sulphates and phosphates indicates that the nutrient concentration of the water is very low. This could be as a result of the combined effect of absorption of the available nutrients by $E$. crassipes and the high rate of self purification by the water body.

\section{REFERENCES}

APHA (1976). Standard Methods for Water and Sewage Analysis, $4^{\text {th }}$ Ed. American Public Health Association, New York, p 230.

Boss, A (1996). Water Hyacinth problem in Tropical Africa. World Bank, New York.

Cook, DK (1976). Water plants of the World. Bank Publishers London, p 250

Center, TD; Spencer, NR (1981). The phenology and growth of water hyacinth (E. crassipes) (Mat solms) in a eutrophic North Central Florida Lake. Aquatic Botany. 10, 1 -32.

Egborge, ABM; Sagay, S (1988). Water Hyacinth in Bendel State. In: Oke, SO; Imevbore, AMA \& Farr, TA (ed.), Proc. International Water on Water Hyacinth (ed.1). pp. 71-75.
Gopal, B (1987). Water Hyacinth. Aquatic mat, Studies Series, ELSEVER, p74.

Harborne, JB (1973). Phytochemical Methods. A Guide to Modern Techniques of Plant Analysis Chapman and Hall Ltd., London. p320

Isichei, TO; Ukpe, UU; John, OO (2003). Production of Paper from Water Hyacinth (Eichhornia crassipes) Journal of Nigerian Environmental Society, 1(3), 413-416.

Mitchell, DS; Thomas, PA (1972). Ecology of Water Weeds in the Neotropics. UNESCO, Paris, France. p150.

Nyananyo, BL; Ekeke, C; Mensah, SI (2005). The Morphology and Phytochemistry of Water Hyacinth. Journal of Creativity and Scientific Studies, $1(2 \& 3), 20-29$.

Onwudinjo, CU (1990).Hydrobiology and plankton of Benin River, Nigeria. Ph.D. Thesis, University of Benin, Nigeria.

Schmitz, DC; Schardt, JD; Leslie, AJ; Dray, FA Jr.; Osborne, JA; Nelson, BV (1993). The Ecological Impact and Management History of three Invasive Alien Plant Species in Florida. In: McKnight, B.N. (ed.). Biological Pollution, the Control and Impact of Invasive Exotic Species. Indiana Academy of Science, Indianapolis, Indiana, USA. p173.

Stewart, EAH; Max Grimshaw, JAP; Christopher, O (1984) Chemical Analysis of Ecological Materials. Blackwell Scientific Publications, Oxford London. p250.

Tabita, A; Woods, JW (1962). History of Hyacinth Control in Florida. Hyacinth Control Journal 1, 19-23.

Tetsola, EA (1988). Distribution and feeding relationship of the Fishes in Warri River, Nigeria. Ph. D. Thesis, University

William, O. O. (1999). Environmental Physiology of Animal and Pollution. 191:239 - 243. 